\title{
Nucleation and growth of biomimetic apatite layers on 3D plotted biodegradable polymeric scaffolds: Effect of static and dynamic coating conditions
}

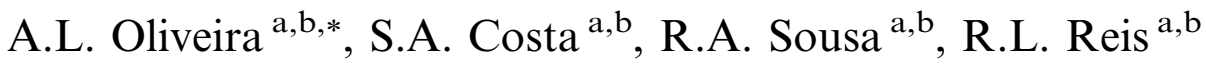 \\ a $3 B$ 's Research Group-Biomaterials, Biodegradables and Biomimetics, Univ. Minho, Headquarters of the European Institute of \\ Excellence on Tissue Engineering and Regenerative Medicine, AvePark, S. Cláudio do Barco, 4806-909 Taipas, Guimarães, Portugal \\ ${ }^{\mathrm{b}}$ IBB-Institute for Biotechnology and Bioengineering, PT Government Associated Laboratory, Guimarães, Portugal
}

Received 12 February 2008; received in revised form 10 December 2008; accepted 10 December 2008

Available online 25 December 2008

\begin{abstract}
Apatite layers were grown on the surface of newly developed starch/polycaprolactone (SPCL)-based scaffolds by a 3D plotting technology. To produce the biomimetic coatings, a sodium silicate gel was used as nucleating agent, followed by immersion in a simulated body fluid (SBF) solution. After growing a stable apatite layer for 7 days, the scaffolds were placed in SBF under static, agitated (80 strokes $\left.\min ^{-1}\right)$ and circulating flow perfusion $\left(Q=4 \mathrm{ml} \mathrm{min}^{-1} ; t_{\mathrm{R}}=15 \mathrm{~s}\right)$ for up to 14 days. The materials were characterized by scanning electron microscopy/energy dispersive X-ray spectroscopy, Fourier transform infrared spectroscopy and thin-film X-ray diffraction. Cross-sections were obtained and the coating thickness was measured. The elemental composition of solution and coatings was monitored by inductively coupled plasma spectroscopy. After only $6 \mathrm{~h}$ of immersion in SBF it was possible to observe the formation of small nuclei of an amorphous calcium phosphate (ACP) layer. After subsequent SBF immersion from 7 to 14 days under static, agitated and circulating flow perfusion conditions, these layers grew into bone-like nanocrystalline carbonated apatites covering each scaffold fiber without compromising its initial morphology. No differences in the apatite composition/chemical structure were detectable between the coating conditions. In case of flow perfusion, the coating thickness was significantly higher. This condition, besides mimicking better the biological milieu, allowed for the coating of complex architectures at higher rates, which can greatly reduce the coating step. (C) 2009 Acta Materialia Inc. Published by Elsevier Ltd. All rights reserved.
\end{abstract}

Keywords: Tissue engineering scaffolding; Starch biodegradable polymer; Biomimetic; Calcium phosphate; Apatite coating

\section{Introduction}

The field of tissue engineering continues to advance with the discovery of new biomaterials, growth factors and scaffold fabrication techniques. In addition to demineralized bone matrix, numerous synthetic [1-3] and naturally [4-6] derived biodegradable porous scaffolds are being proposed for use as bone graft substitutes, and as delivery vehicles

\footnotetext{
* Corresponding author. Address: 3B's Research Group-Biomaterials, Biodegradables and Biomimetics, Univ. Minho, Headquarters of the European Institute of Excellence on Tissue Engineering and Regenerative Medicine, AvePark, S. Cláudio do Barco, 4806-909 Taipas, Guimarães, Portugal. Tel.: +351 253 604781; fax: +351253604492.

E-mail address: analeite@dep.uminho.pt (A.L. Oliveira).
}

for bioactive factors and osteogenic cells. Among these, starch-based polymeric systems are particularly interesting due to their well-established biocompatibility $[7,8]$ and processing versatility [9-13]. Concurrently, a variety of techniques for the processing of porous scaffolds have been reported [1-3,14-16]. However, most of the conventional fabrication techniques currently available do not meet the desired properties, as many of the processing routes still depend heavily on manual intervention. This results in inconsistent and inflexible processing procedures. Rapid Prototyping (RP) technologies are considered as potential routes for the production of complex scaffolds for tissue engineering applications, as they present superior control over design, manufacturing and reproducibility of tissue 
engineering scaffolds [16,17]. Moreover, when coupled with adequate image acquisition software, RP allows for the production of anatomically adapted three-dimensional (3D) scaffolds based on the patient's own defect. In addition, the scaffold architecture can be tailored to present different symmetries. A clear example of the potential of these technologies is the work carried out by Hutmacher et al. [1] in exploring the fused deposition modeling technique for the development of polycaprolactone (PCL) scaffolds.

From a tissue engineering point of view, the advantageous characteristics of fiber-based scaffolds include a large surface area for enhancing cell attachment and rapid diffusion of nutrients which favours cell survival and proliferation [18]. Moreover, provision of the appropriate surface chemistry for cell attachment and proliferation is another key issue that needs to be addressed. In this sense a challenging, though attractive, approach to better induce bone formation is to promote the mineralization of a bone-like calcium phosphate (generically designated as $\mathrm{Ca}-\mathrm{P}$ or "apatite") layer on the outermost surface of the scaffold. $\mathrm{Ca}-\mathrm{P}$ minerals found in natural hard tissues are produced spontaneously in a physiological environment at low temperatures from moderately supersaturated mineralizing solutions [19]. To learn, understand and apply these natural processes for producing $\mathrm{Ca}-\mathrm{P}$ coatings biologically identical to bone apatite has been the focus of the attention of many researchers in the recent years, as reviewed elsewhere [20].

The so-called biomimetic preparation of calcium phosphate coatings on implant materials has thus emerged as a new concept. This process was initially proposed by Kokubo et al. [21] who used solutions that were able to mimic the inorganic composition of the human blood plasma, i.e. simulated body fluid (SBF) solutions. Besides its osteoconductive properties, a biomimetic apatite layer has a carrier potential due to the physiological operating conditions of temperature and $\mathrm{pH}$. In fact, these coatings can serve as vehicles for the release of biologically relevant molecules such as protein growth factors, enzymes or pharmaceutical drugs used in bone-related diseases. So far, this potential has not been fully exploited.

To effectively coat an apatite layer on the surface of a biodegradable polymeric scaffold, while ensuring a homogeneous coating distribution throughout the entire surface of the pores without compromising its initial shape, represents an enormous challenge, due to complex features such as the coating composition, thickness distribution or the adhesion to the substrate. Moreover, $\mathrm{pH}$ changes due to possible degradation of substrates surface during the coating process have also to be taken into consideration. Nevertheless, in our research group these biomimetic coatings could be effectively produced on the surface of starch-based biodegradable polymers [22,23], namely by developing a biomimetic methodology using a sodium silicate gel as nucleating agent. This methodology has still room for improvement concerning the control of the apatite thickness and its distribution throughout the scaffold.
Most recently, the majority of the biomimetic routes proposed for coating of $\mathrm{Ca}-\mathrm{P}$ layers on the surface of biomaterials have been limited to static conditions [22,24-30]. However, in vivo, the mineralization of bone tissue occurs in the presence of body fluids that continuously circulate in the body [31]. Therefore, an in vitro biomimetic approach including dynamic studies is of great significance as it comes closer to the in vivo scenario, where the flow of human body fluids may have an effect on the formation of bone apatite [32]. A few authors [33-37] have studied the mineralization of apatite layers under dynamic conditions, though these studies were only intended to better assess the bioactive behaviour of silica-based bioceramics. These materials are highly reactive and cause a local decrease of $\mathrm{Ca}^{2+}$ and $\mathrm{PO}_{4}^{3-}$ in the surrounding solution during apatite formation in static conditions, which will compromise the progress of the mineralization process. When considering 3D porous architectures that are not bioactive per se, dynamic mineralization environments can also be suitable to promote a homogeneous formation of the $\mathrm{Ca}-\mathrm{P}$ layer on its interior. This work studies the nucleation of apatite layers on the surface of starch polycaprolactone (SPCL) scaffolds produced by a 3D plotting technology, and its subsequent growth under different static and dynamic mineralizing conditions.

\section{Materials and methods}

\subsection{Preparation of the scaffolds}

As polymers of natural origin, starch-based biomaterials exhibit great potential for use in bone-related applications [38-41]. In this work, the studied material is based on a blend of starch/PCL. The blend contains around 30\% starch by weight. The selected biomaterial presents a good biological behaviour and has been proposed for bone tissue engineering applications by using other fiber-based processing routes such as fiber bonding $[12,42-44]$ and by combining this technique with electrospinning to generate nano- and microfiber 3D architectures [12].

SPCL scaffolds were produced, using a 3D plotting technology (Bioplotter, EnvisionTec $\mathrm{GmbH}$, Germany). In this case alternating layers with a $0^{\circ} / 90^{\circ} / 0^{\circ} / 90^{\circ}$ orientation period were plotted. The resulting pattern has generated an offset that will increase the level of asymmetry. Cubic samples with a lateral side of $L=5 \mathrm{~mm}$ were produced.

\subsection{Apatite coating formation}

To produce an apatite coating on the surfaces of the obtained SPCL scaffolds a biomimetic methodology was used based on a previously developed sodium silicate methodology [22]. The samples were "impregnated" for $1 \mathrm{~h}$ with a sodium silicate gel from Sigma-Aldrich $\left(\mathrm{Na}_{2} \mathrm{SiO}_{3} \cdot \mathrm{H}_{2} \mathrm{O}\right.$, containing $\sim 14 \% \mathrm{NaOH}$ and $\sim 27 \% \mathrm{SiO}_{2}, \mathrm{pH} \approx 13$ ), under mild agitation. This sodium silicate gel was used herein with the concentration and $\mathrm{SiO}_{2} / \mathrm{Na}_{2} \mathrm{O}$ molar ratio as 
received. After this treatment the solution with the samples was diluted with 50 vol.\% distilled water and stirred for $5 \mathrm{~min}$. This procedure was aimed at diminishing the viscosity of the gel in order to produce a homogeneous and thin layer of vitrified sodium silicate on the surface of the materials. The scaffolds were then removed from the solution and dried in vacuum for $3 \mathrm{~h}$ and in a controlled atmosphere $\left(23 \pm 1{ }^{\circ} \mathrm{C} ; 55 \%\right.$ relative humidity $\left.(\mathrm{RH})\right)$ for $24 \mathrm{~h}$. A more detailed description on the coating methodology can be found elsewhere [22].

An aqueous solution was prepared comprising all major inorganic ions present in human blood plasma, and presenting its approximate ion concentration, in order to promote in vitro apatite formation. The different salts were dissolved in deionized $\mathrm{H}_{2} \mathrm{O}$ and the $\mathrm{pH}$ adjusted to neutral using tris(hydroxymethyl)aminomethane and hydrochloric acid. This SBF was developed by Kokubo et al. [45].

The as-treated scaffolds were immersed in the SBF solution for 7 days. During this period the solution was renewed every 2 days and an apatite layer was allowed to nucleate and grow on the surface of the samples. Following this period, the samples were divided into three different groups and placed in contact with a renewed SBF solution under different conditions: static, agitated by shaking $\left(80\right.$ strokes $\min ^{-1}$ ) in a thermostatic bath (Selecta, Unitronic, Spain) and circulating flow perfusion in a bioreactor

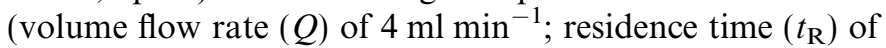
$15 \mathrm{~s})$ for periods of up to 14 days. In all conditions the total volume of SBF available per sample was $50 \mathrm{ml}$ and the solution was renewed every 2 days (solid-to-liquid ratio of $1 \mathrm{~g} / 400 \mathrm{ml} /$ week). Table 1 summarizes the different coating conditions.

For the final condition a special bioreactor [46] was designed as shown schematically in Fig. 1.

After 7 and 14 days the samples were removed from solution, washed in distilled water and dried in a controlled atmosphere $\left(23 \pm 1{ }^{\circ} \mathrm{C} ; 55 \% \mathrm{RH}\right)$.

\subsection{Scanning electron microscopy and energy dispersive spectroscopy}

The morphological characterization of the scaffolds was carried out by Scanning Electron Microscopy (SEM) in a Leica Cambridge S360. All the samples were coated with a thin film of carbon, by ion sputtering, prior to any observation. The electron beam energies were 10 and $12 \mathrm{KeV}$. The scaffolds were observed in three different orientations:

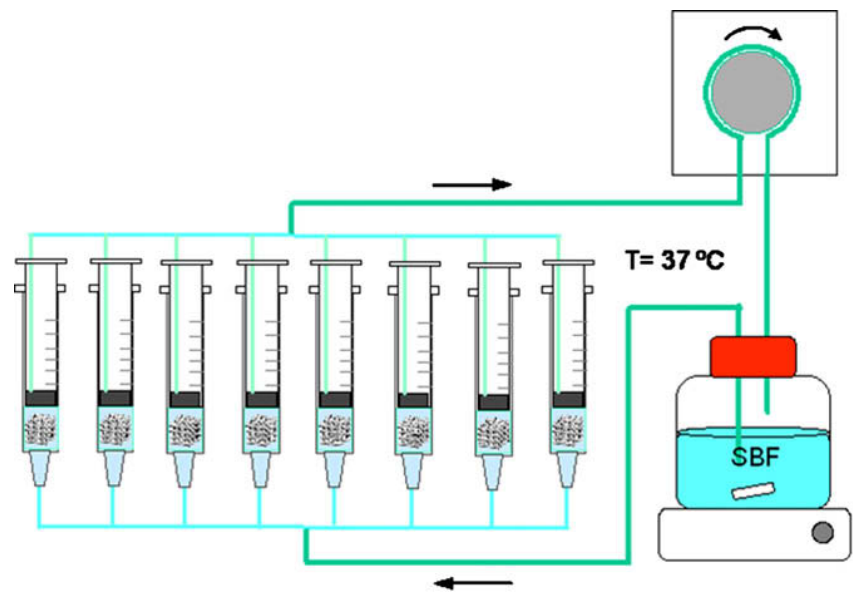

Fig. 1. Schematic drawing of the bioreactor designed for coating an apatite layer under flow perfusion.

from the top, lateral side and bottom, for the different tested periods and conditions in SBF. The corresponding cross-sections were also analyzed and the thickness of the apatite layers was calculated by performing measurements in six fibers per scaffold (three measurements per fiber). Since these coatings are constituted by fused spherical apatite nuclei they present an irregular surface. Therefore, in order to ensure that the measure would be done in the same way for all the conditions, the basis of these nuclei was established as the limit for the coating. Hence, the measured average values are the minimum thickness values for all the samples.

\subsection{X-ray diffraction}

Thin-film X-ray diffraction (TF-XRD; Philips X'Pert MPD) was used to identify any crystalline phases present in the apatite layers formed during the immersion in SBF. The data collection was performed by the $2 \theta$ scan method with $1^{\circ}$ as the incident beam angle using $\mathrm{Cu} K_{\alpha}$ radiation and a scan speed of $0.05^{\circ} \mathrm{min}^{-1}$ in $2 \theta$.

\subsection{Fourier transform infrared spectroscopy}

The chemical structure of the apatite coatings formed on the surface of the SPCL scaffold fibers after the different periods and conditions in SBF was analyzed by Fourier Transform Infrared (FTIR) spectroscopy. The surface of the fibers was scratched and the resulting particles were

Table 1

Static and dynamic conditions for coating apatite layers on the SPCL scaffolds.

\begin{tabular}{lllll}
\hline Periods (days) & SBF & Conditions & & \\
\hline 7 & $1 \times$ & Static & & Flow perfusion \\
\cline { 2 - 5 } 14 & $1 \times$ & Static & Agitated & $50 \mathrm{ml}$ \\
\hline Volume of SBF available per sample & $50 \mathrm{ml}$ & $50 \mathrm{ml}$ & $1 \mathrm{~g} / 400 \mathrm{ml} /$ week \\
Solid-to-liquid ratio & & $1 \mathrm{~g} / 400 \mathrm{ml} /$ week & $1 \mathrm{~g} / 400 \mathrm{ml} /$ week & Laminar flow $\left(Q=4 \mathrm{ml} \mathrm{min}{ }^{-1} ; t_{\mathrm{R}}=15 \mathrm{~s}\right)$ \\
Fluid flow & None & Turbulent flow $\left(80\right.$ strokes $\left.\min ^{-1}\right)$ & \\
\hline
\end{tabular}


milled with $\mathrm{KBr}$ powder and shaped by compression into pellets for further analysis. All spectra were recorded using 64 scans and $2 \mathrm{~cm}^{-1}$ resolution in an FTIR spectrophotometer (Perkin-Elmer 1600 Series).

\subsection{Inductively coupled plasma spectroscopy}

The composition of the Ca-P coatings was assessed by analyzing the solution resulting from dissolving the coated scaffolds in $0.1 \mathrm{M} \mathrm{HCl}$, under agitation for $24 \mathrm{~h}$ (the scaffolds were examined by SEM afterwards to confirm the total dissolution of the coating at the surface). The elemental concentration was measured by inductively coupled plasma optical emission spectroscopy (ICP-OES1 JY 70 plus, Jobin Yvon, France). Duplicate samples were analyzed for each condition and immersion time. From these results $\mathrm{Ca} / \mathrm{P}$ ratios were calculated. Considering the possibility of $\mathrm{Mg}^{2+}, \mathrm{Na}^{+}$and $\mathrm{K}^{+}$, present in the SBF, substituting the $\mathrm{Ca}^{2+}$ in the crystalline network of the apatite, the following relations were also considered: $(\mathrm{Ca}+\mathrm{Na}+$ $\mathrm{Mg}+\mathrm{K}) / \mathrm{P} ;(\mathrm{Ca}+\mathrm{Mg}+\mathrm{K}) / \mathrm{P} ; \mathrm{Na} / \mathrm{Ca} ; \mathrm{Mg} / \mathrm{Ca} ; \mathrm{K} / \mathrm{Ca}$.

The evolution of the elemental composition of the solution during the coating formation was also monitored by ICP. The concentration of $\mathrm{Ca}, \mathrm{P}, \mathrm{Na}, \mathrm{Mg}, \mathrm{K}$ and $\mathrm{Si}$ elements was measured after 3,6 and $24 \mathrm{~h}$, and 2, 5, 7 and 15 days. From the obtained concentration of ions consumed or released to the solution at each time point the cumulative concentration was calculated according to the following equation:

$\mathrm{C}=\sum\left(\left[\mathrm{C}_{n}\right]-\left[\mathrm{C}_{n+1}\right]\right)$

\section{Results}

\subsection{Nucleation of the apatite layer}

Fig. 2 presents SEM micrographs of the morphology of the obtained SPCL scaffolds after plotting using the RP technology.

This technology enables superior control over scaffold morphology, resulting in the fabrication of scaffolds with controlled porosity and interconnectivity. Moreover, the applied plotting technique allowed for the processing of fiber-based 3D constructs with a controlled morphology and porosity (around $70 \%$ ) in a reproducible manner. The average diameter of the produced fibers was around $500 \mu \mathrm{m}$.

Fig. 3 presents the scaffolds treated with sodium silicate and after different periods in SBF up to 7 days.

Sodium silicate treatment followed by immersion in the SBF solution for 7 days resulted in the nucleation of a welldefined apatite layer covering the entire surface of the fibers, while maintaining their initial porous structure and interconnectivity (Fig. 3a-f). This biomimetic methodology was for the first time applied to coat 3D plotted starch biodegradable scaffolds. After only $6 \mathrm{~h}$ of immersion in SBF
(Fig. 3b) it was possible to observe the formation of small spherulitic precipitates at the surface of the scaffolds with an approximate size of a few tens of nanometres, aggregated into a layer. With increasing time of immersion the initially formed nuclei have grown to form a continuous layer composed of a globular structure clearly observed after 5 days of immersion and subsequently (Fig. 3e and f). At higher magnifications, it is possible to detect a needle-like nanostructure that is characteristic of $\mathrm{Ca}-\mathrm{P}$ coatings formed under the present biomimetic conditions.

Fig. 4 presents the FTIR and XRD spectra obtained from untreated scaffolds, after the treatment with sodium silicate and after subsequent immersion in SBF up to 7 days.

In Fig. 4a the IR bands were assigned according to previous studies [47-49]. The IR spectrum of the SPCL blend revealed the presence of the main characteristic bands of corn starch and PCL. The band at $1150-1040 \mathrm{~cm}^{-1}$ is related to the $-\mathrm{C}-\mathrm{O}-\mathrm{C}-$ in glycosidic bonds of starch [47]. The characteristic band of PCL is located at $1726 \mathrm{~cm}$ ${ }^{-1}$, corresponding to the $\mathrm{C}=\mathrm{O}$ stretch ester carbonyl group [48]. The peaks at $1600-1580$ and $1200-1000 \mathrm{~cm}^{-1}$ are related to asymmetric stretch of $-\mathrm{COO}-$ and the stretch of the $-\mathrm{C}-\mathrm{O}$ bond at the main polymer chain [48].

Analyzing the spectrum corresponding to sodium silicate removed from the surface of the scaffolds before immersion in the SBF solution it is possible to detect five different bands, as reported before by Takadama et al. [49]. At $470 \mathrm{~cm}^{-1}$ a band corresponding to the bending of the $\mathrm{Si}-\mathrm{O}-\mathrm{Si}$ bond is identified; another band appears at $800 \mathrm{~cm}^{-1}$, corresponding to the stretching mode of the same bond; the band identified at $950 \mathrm{~cm}^{-1}$ corresponds to the $\mathrm{Si}-\mathrm{O}-\mathrm{Na}$ stretching bond; the bands at 1090 and $1200 \mathrm{~cm}^{-1}$, are related to stretching of the $\mathrm{Si}-\mathrm{O}$ bond. The bands detected at $1638 \mathrm{~cm}^{-1}$ are assigned to water molecules present in the sodium silicate structure.

The IR analysis performed on the coatings removed from the surface of the scaffolds during the first periods of immersion in SBF (up to $48 \mathrm{~h}$ ) revealed the presence of $\mathrm{Si}-\mathrm{O}$ stretching bonds which are ascribed to the sodium silicate, which contains an abundance of in $\mathrm{Si}-\mathrm{OH}$ groups [50]. After $6 \mathrm{~h}$ a band ascribed to $\mathrm{P}-\mathrm{O}$ bending bonds is revealed at $590 \mathrm{~cm}^{-1}$, attributed to the formation of amorphous calcium phosphate (ACP) [51]. This band started to dissociate into two new bands after $48 \mathrm{~h}$, which were assigned to the $v_{4}$ bending mode of the $\mathrm{O}-\mathrm{P}-\mathrm{O}$ bonds which are characteristic of more crystalline apatites. After 5 and 7 days these two bands have increased in intensity and could be detected at 602 and $564 \mathrm{~cm}^{-1}$. The band at $1032 \mathrm{~cm}^{-1}$ indicates the $v_{3}$ stretching mode of $\mathrm{P}-\mathrm{O}$ bonds [51], and has also increased in intensity with time. The bands at 876,1424 and $1462 \mathrm{~cm}^{-1}$ result from the presence of carbonate $\left(\mathrm{CO}_{3}^{2-}\right)$ incorporated in the apatite lattice [51,52]. The presence of these bands clearly indicates that a carbonated apatite was formed, similar to the one found in bone apatite.

In Fig. $4 \mathrm{~b}$ the presented XRD peaks were assigned according with the literature $[22,23]$. The peaks detected 

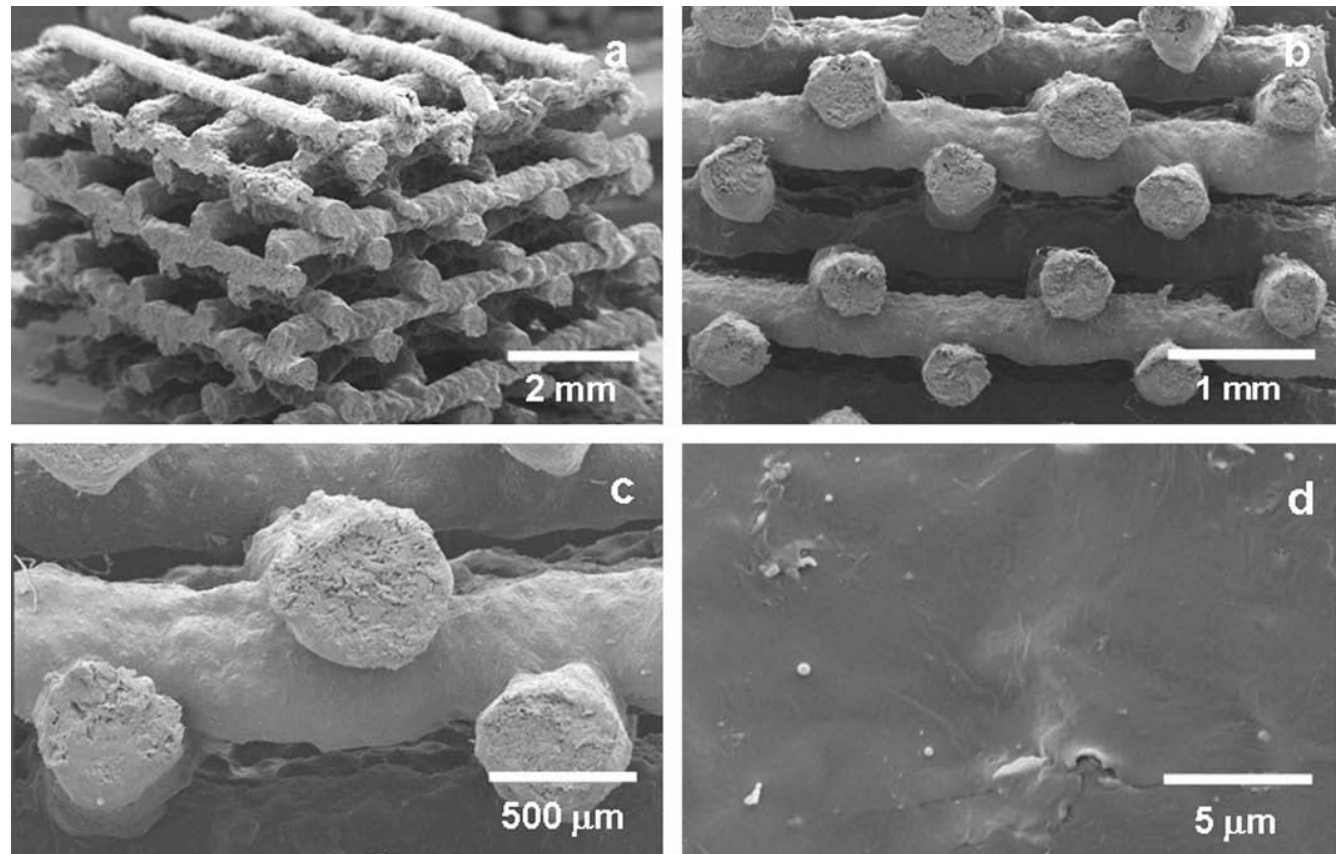

Fig. 2. SEM micrographs of (a) a scaffold obtained with the Bioplotter ${ }^{\circledR}$ technology; (b) lateral view of the scaffold and, respective magnifications showing details of (c) the adhesion of the fibers and (d) their surface morphology.
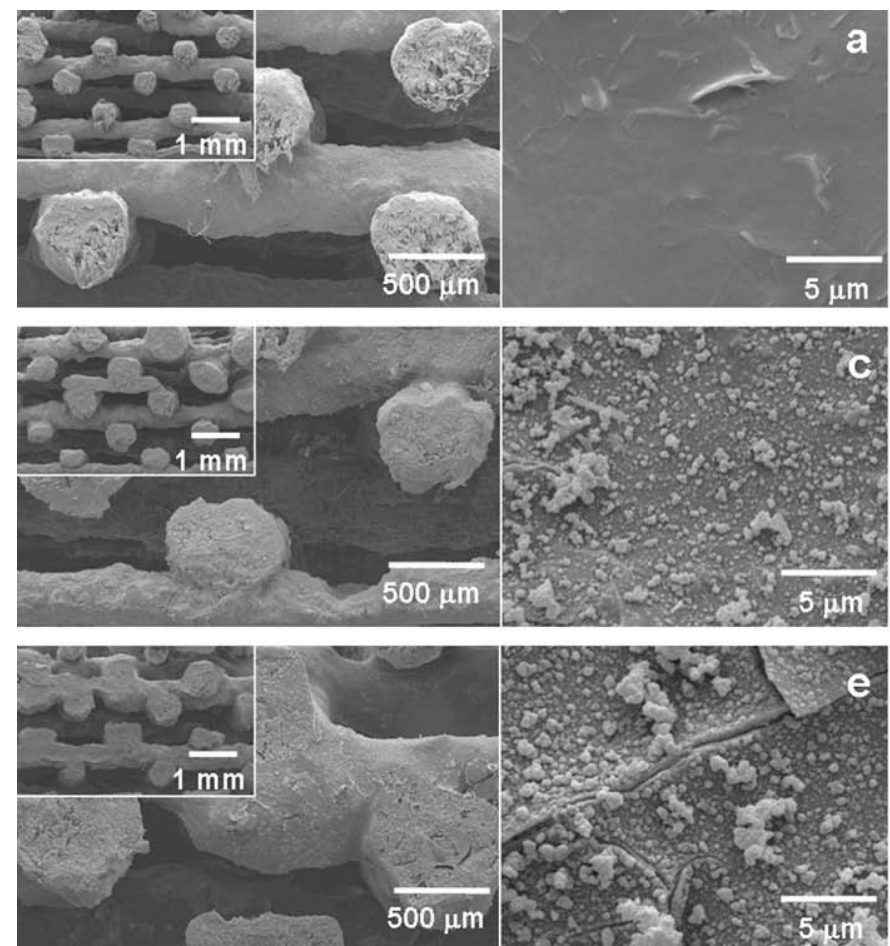
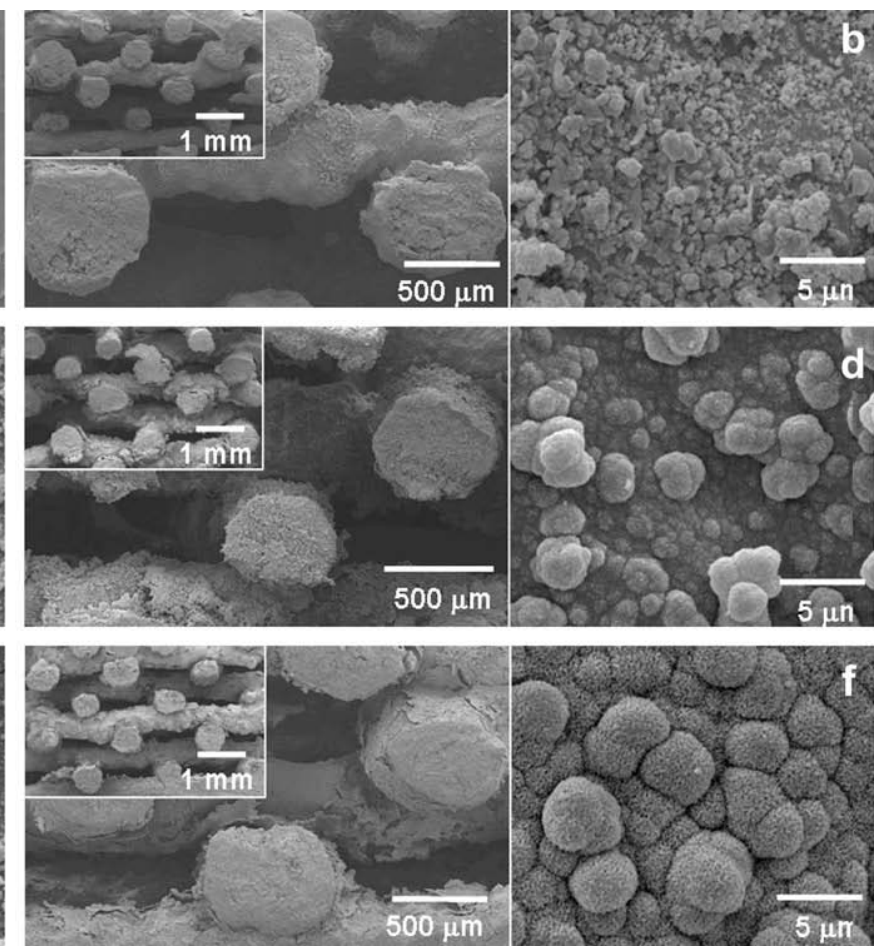

Fig. 3. SEM micrographs of the scaffolds (a) treated with sodium silicate and after different periods in SBF: (b) 6 h and (c) 24 h, (d) 2 days, (e) 5 days and (f) 7 days, showing the evolution of the apatite layer in the nucleation stage.

at $2 \theta=20^{\circ}, 21^{\circ}$ and $24^{\circ}$ are assigned to SPCL crystalline phases [23]. After the treatment with sodium silicate and subsequent immersion in SBF, no changes in the XRD profiles were detected in the first $48 \mathrm{~h}$, indicating that the ini- tially formed $\mathrm{Ca}-\mathrm{P}$ layer exhibited and amorphous character. After 5 days the main two characteristic peaks attributed to HA started to be detected, and have increased in intensity after 7 days, due to an increase in the crystallin- 

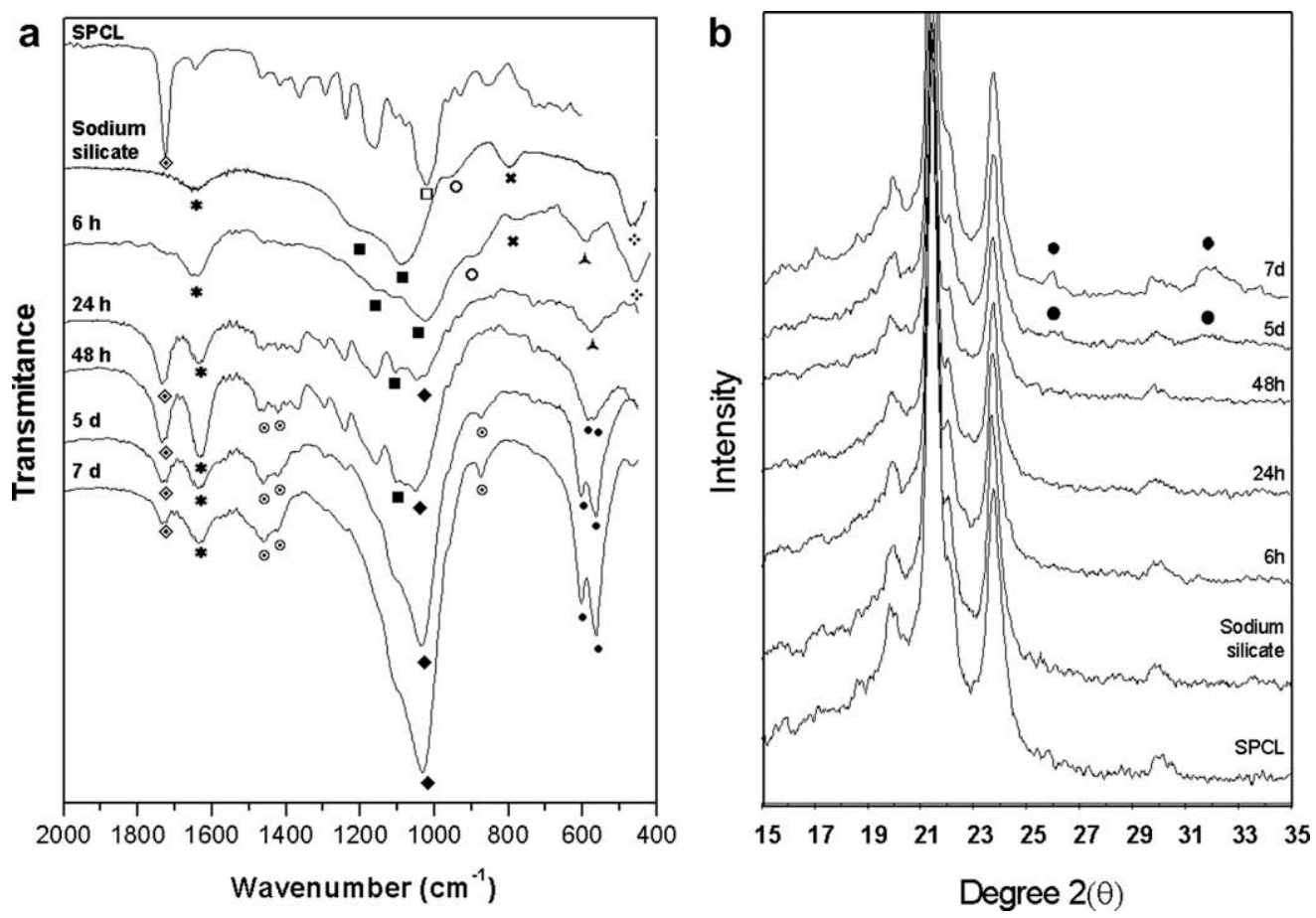

Fig. 4. FTIR and TF-XRD spectra of the scaffolds treated with sodium silicate and after different periods in SBF up to 7 days. (a) $\mathbf{\square}-\mathrm{C}-\mathrm{O}-\mathrm{C}-$, $\$$

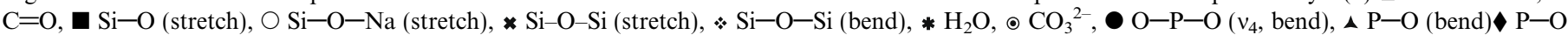
$\left(v_{3}\right.$, stretch). (b) main characteristic peaks assigned to hydroxyapatite.

ity and in the thickness of the apatite layer. The broad peak at $2 \theta=26^{\circ}$ is assigned to the (002) plane in the lattice of the apatite crystals. Another important diffraction peak is detected around $2 \theta=32^{\circ}$ and is related to the overlapping of planes (211), (112) and (300). Together with FTIR data it was possible to confirm that a poorly crystalline carbonated apatite similar to bone was formed.

Fig. 5 presents the variation of $\mathrm{Ca}, \mathrm{P}, \mathrm{Si}, \mathrm{Mg}, \mathrm{Na}, \mathrm{K}$ and $\mathrm{Si}$ concentrations in the SBF solution during the first week of the biomimetic treatment (Fig. 5a and b) and also the elemental ratios calculated after dissolution of apatite layers formed during the same time period (Fig. $5 \mathrm{c}$ and d).

When considering the ionic composition of the SBF solution, it was observed that during the coating process a simultaneous drop in the concentration levels of $\mathrm{Ca}$ and $\mathrm{P}$ ions is observed, indicating that a $\mathrm{Ca}-\mathrm{P}$ is being formed by consuming these ions from solution (Fig. 5a). During this process, $\mathrm{Ca}$ and $\mathrm{P}$ are being consumed at a higher rate in the first hours and from then on more gradually. Initially, the presence of the sodium silicate at the surface of the scaffolds have induced the formation of a large number of $\mathrm{Ca}-\mathrm{P}$ nuclei during the first $6 \mathrm{~h}$ of immersion in SBF, as shown in Fig. 3. Once stabilized, these nuclei have grown to form a continuous apatite layer, consuming $\mathrm{Ca}$ and $\mathrm{P}$ at a lower rate. A small decrease in the $\mathrm{Mg}$ concentration was observed in the first hours of immersion, indicating that this element could be incorporating the structure of the first formed apatite nuclei. On the other hand, when analyzing the evolution of $\mathrm{Na}$ and $\mathrm{Si}$ in solu- tion (Fig. 5b), an accentuated increase in their concentrations was observed initially, which is attributed to the dissolution of the sodium silicate from the surface, thus creating at the near surface the adequate environment for growth and nucleation of the apatite. The variation of the $\mathrm{K}$ concentration was considered irrelevant during the studied period of apatite formation, indicating that this element is not participating in the nucleation process.

$\mathrm{The} \mathrm{Ca} / \mathrm{P}$ ratio of the apatite nuclei formed after the first $6 \mathrm{~h}$ of immersion in SBF (Fig. 5c) was around 1.48, which is close to the value attributed to tricalcium phosphate (TCP, $\mathrm{Ca} / \mathrm{P}=1.50$ ). The results obtained from FTIR and XRD analysis (Fig. 4) indicate that the first calcium phosphate nuclei to be formed presented an amorphous nature. In this way an amorphous phase (ACP) corresponding to a TCPlike composition was formed. A slow increase in the $\mathrm{Ca} / \mathrm{P}$ ratio up to 1.54 was observed over time of immersion in $\mathrm{SBF}$ up to 7 days. The $\mathrm{Ca} / \mathrm{P}$ ratio of stoichiometric hydroxyapatite $\left(\mathrm{Ca}_{10}\left(\mathrm{PO}_{4}\right)_{6}(\mathrm{OH})_{2} \cdot 10 \mathrm{H}_{2} \mathrm{O}\right)$ is 1.67 . In this way, the obtained apatite is $\mathrm{Ca}$ poor. When considering the presence of $\mathrm{Na}, \mathrm{Mg}$ or $\mathrm{K}$ in the apatite structure, the obtained values for the elemental ratios increased, mostly in the first days of immersion in the SBF (Fig. 5c). By analyzing the individual contribution of each element (Fig. 5d) it is possible to observe that this increase has been attributed to $\mathrm{Na}$ and $\mathrm{Mg}$. The detection of considerable amounts of $\mathrm{Na}$ in the apatites formed in the first hours can be justified by the presence of sodium silicate during the nucleation stage. This ion will be mostly physically adsorbed in the 

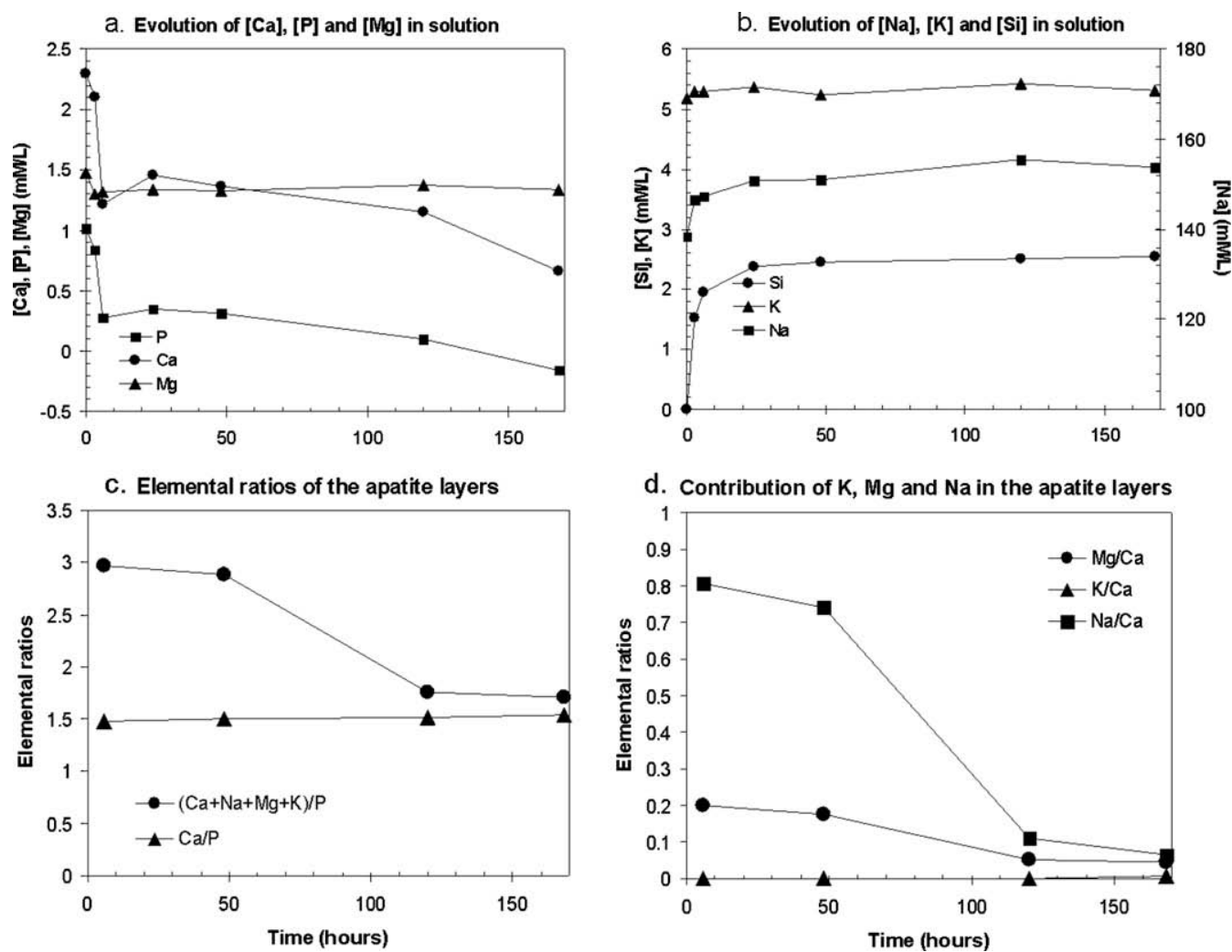

Fig. 5. Evolution of the elemental concentration of SBF solution ( $a$ and $b$ ) and of the elemental ratios of the obtained apatite layers (c and d) measured by ICP analysis for different periods up to 7 days.

apatite structure. On the other hand, it is known that $\mathrm{Mg}$ can be easily accommodated in the structure of ACP by substituting $\mathrm{Ca}$, causing local deformation with eventual shrinking of the columns of calcium and distortion of $\mathrm{PO}_{4}$ polyhedra, as magnesium has a lower ionic radius than calcium ( 0.66 vs. $0.99 \AA)$ and a shorter bond length with oxygen $(\mathrm{Mg}-\mathrm{O}$ is about $2.1 \AA$, whereas $\mathrm{Ca}-\mathrm{O}$ in $\mathrm{HA}$ is in the range $2.443-2.555 \AA$ ) [53]. The presence of this ion will stabilize the initially formed amorphous $\mathrm{Ca}-\mathrm{P}$ nuclei and is believed to ensure their chemical bonding to the substrate [28]. Due to mechanical strains induced by $\mathrm{Mg}$ ions, nucleation of HA is hindered and will only start to form when $\mathrm{Mg}$ ions leave the structure. In fact, after $48 \mathrm{~h}$ of immersion in SBF the level of $\mathrm{Mg}$ decreases together with $\mathrm{Na}$, indicating that these ions leave the $\mathrm{Ca}-\mathrm{P}$ structure. This compositional evolution occurred together with an increase in the crystallinity of the apatite structure. The mechanism for the nucleation and growth of an apatite layer on a sodium silicate gel has been previously studied by Takadama et al. [49,50] and Miyagi et al. [54]. In brief, a calcium phosphate layer is grown as a consequence of electrostatic interactions of negatively charged $\mathrm{Si}-\mathrm{O}$ units, formed by dissociation of the $\mathrm{Si}-\mathrm{OH}$ groups, with the positively charged calcium ions in the fluid. A positively charged calcium silicate layer is then formed which will interact with the negatively charged phosphate ions in the fluid to form an ACP, which then stabilizes into a nanocrystalline apatite layer. The resulting $\mathrm{Ca}-\mathrm{P}$ coating presents a needle-like structure (see Fig. 3) corresponding to the typical morphology obtained by this biomimetic route in previous work by the authors [22]. This coating was present both in the outside and in the interior of the scaffold. Apatite nucleation was clearly controlled by the surface, which has served as a template for the mineralization process.

\subsection{Growing of the apatite layer under static and dynamic conditions}

After 7 days of immersion in static SBF, the samples were divided into three groups and immersed in another SBF solution under three different hydrodynamic conditions: static, agitation and flow perfusion for periods of up to 14 days. As said before, this new biomimetic approach is intended to produce, for the first time, apatite coatings on the surface of the newly developed SPCL scaffolds without compromising its initial porosity or interconnectivity. Fig. 6 presents typical FTIR and TF-XRD spectra of the apatite coatings produced in the different SBF conditions, for a period of 14 days.

FTIR spectra and TF-XRD results (Fig. 6a and b, respectively) confirm that a poorly crystalline carbonated apatite similar to bone was formed after 14 days of immersion in SBF. By the present techniques it was not possible to assess any clear modification of the chemical structure or crystallinity of the apatite layers when dynamic flows were present. In the same way, the analysis performed on the top 

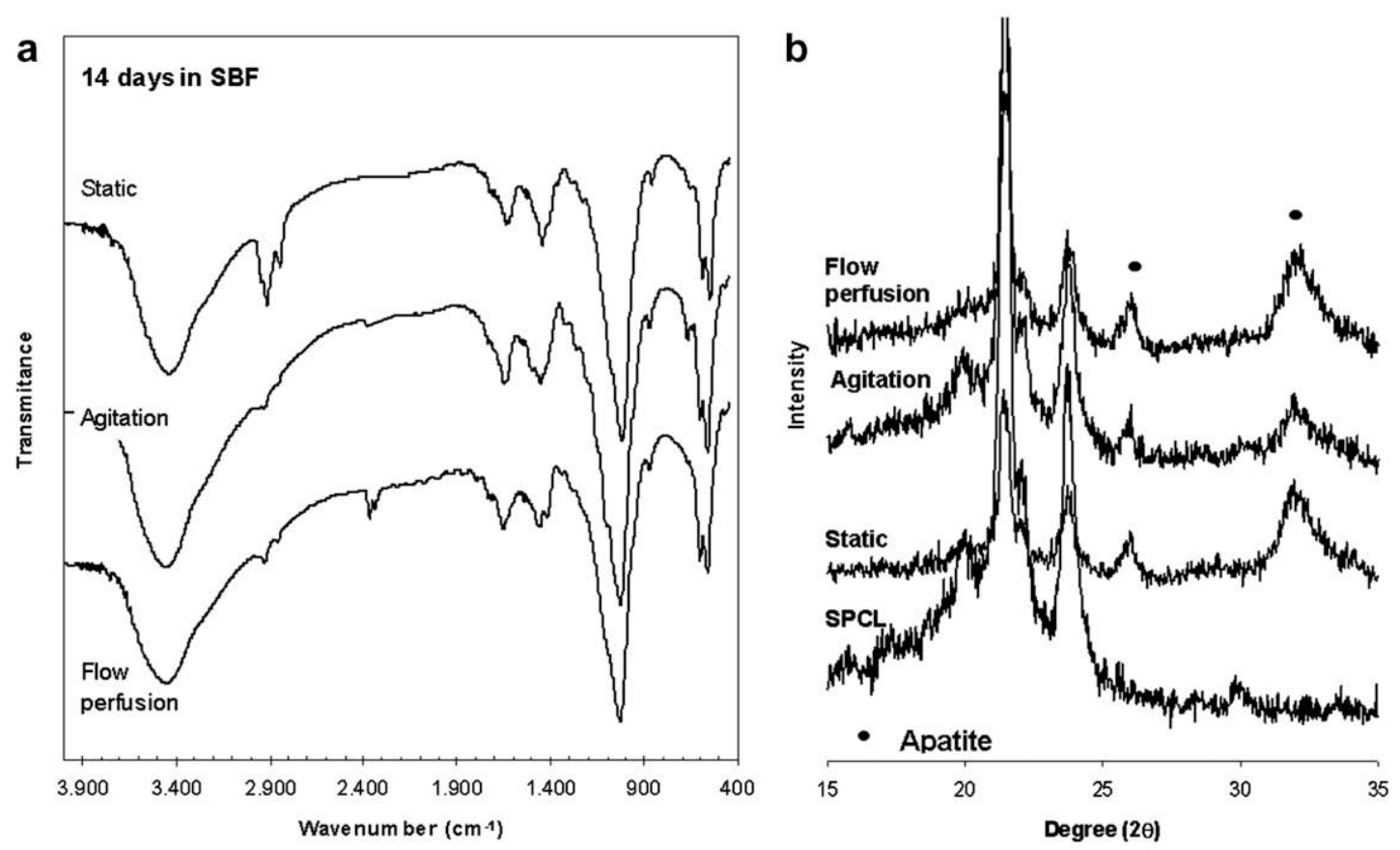

Fig. 6. FTIR (a) and XRD (b) spectra obtained from the analysis of the SPCL scaffolds after immersion in SBF for 14 days from which the last 7 days were in static or dynamic conditions.

and bottom sides of each scaffold did not reveal any significant modification of the obtained spectra, and the presented results are representative of the obtained profiles for the overall coated scaffolds.

The variation of $\mathrm{Ca}, \mathrm{P}, \mathrm{Mg}, \mathrm{Na}$ and $\mathrm{Si}$ concentrations in the SBF solution from 7 to 14 days under the different studied conditions is presented in Table 2.

From 7 to 14 days of immersion in SBF under the different studied conditions a decrease in $\mathrm{Ca}$ and $\mathrm{P}$ ions was observed due to the growth of the apatite layer. Particularly in the case of flow perfusion the amount of $\mathrm{Ca}$ and $\mathrm{P}$ consumed from solution was clearly higher, indicating that the apatite has grown at a faster rate. The decrease in $\mathrm{Mg}$ ions in solution was very low under all conditions, indicating that only very small amounts of this ion are substituting for $\mathrm{Ca}$. On the other hand, dynamic conditions have allowed for the release of more $\mathrm{Na}$ ions from the coating during the growing of the apatite layer. This can be explained considering that the SBF will flow through the coating, reaching the first layers near the surface and leaching out any adsorbed ions in the structure, particularly $\mathrm{Na}$ from the sodium silicate treatment. The $\mathrm{Ca} / \mathrm{P}$ ratio obtained from the $\mathrm{Ca}$ and $\mathrm{P}$ consumed in solution indicates that a Ca-deficient apatite is being formed, and that this deficiency increased under dynamic conditions.

Table 3 presents the elemental ratios calculated after dissolution of apatite layers formed under the different conditions in SBF after 14 days.

ICP analysis of the solutions obtained from dissolving the apatite coatings allowed a comparison of the chemical compositions of the coatings prepared under the different biomimetic conditions in SBF after 14 days. The $\mathrm{Ca} / \mathrm{P}$ ratios obtained for the apatite layers formed under static, agitated and flow perfusion conditions are consistent with obtained values calculated from solution (Table 2). A higher amount of $\mathrm{Na}$ was detected in the case of static condition, which is also in agreement with the obtained values from solution. In the case of $\mathrm{Mg}$, no significant differences were detected in the obtained apatites. Besides the chemical structure and crystallinity, the chemical composition of the apatite layers was also not significantly altered by the presence of dynamic flow conditions.

The morphology of the resulting apatite layers formed under these conditions was compared by means of SEM examination to the top, bottom and lateral sides of the cubic scaffolds.

Table 2

Variation of the elemental concentration of the solution from 7 to 14 days $\left(\mathrm{mM}^{-1}\right)$ calculated from the ICP measured values.

\begin{tabular}{|c|c|c|c|c|c|c|}
\hline \multirow[t]{2}{*}{ Condition } & \multicolumn{3}{|c|}{ Consumed $\left(\mathrm{mM} \mathrm{l}^{-1}\right)$} & \multicolumn{2}{|c|}{ Released $\left(\mathrm{mM}^{-1}\right)$} & \multirow{2}{*}{$\begin{array}{l}\mathrm{Ca} / \mathrm{P} \text { from } \\
\text { Solution }\end{array}$} \\
\hline & $\Delta[\mathrm{Ca}]$ & $\Delta[\mathrm{P}]$ & $\Delta[\mathrm{Mg}]$ & $\Delta[\mathrm{Si}]$ & $\Delta[\mathrm{Na}]$ & \\
\hline Static & 0.86 & 0.58 & 0.01 & 0.01 & 0.26 & 1.51 \\
\hline Flow perfusion & 1.05 & 0.70 & 0.06 & 0.02 & 1.10 & 1.49 \\
\hline
\end{tabular}


Table 3

$\mathrm{Ca} / \mathrm{P},(\mathrm{Ca}+\mathrm{Na}+\mathrm{Mg}+\mathrm{K}) / \mathrm{P}, \mathrm{Mg} / \mathrm{Ca}$ and $\mathrm{Na} / \mathrm{Ca}$ ratios calculated from the dissolved apatite layers after the biomimetic coating in static and dynamic conditions after 14 days of immersion in $\mathrm{SBF}$.

\begin{tabular}{llllll}
\hline Time (days) & $\mathrm{Ca} / \mathrm{P}$ & $\mathrm{Na} / \mathrm{Ca}$ & $\mathrm{Mg} / \mathrm{Ca}$ & $\mathrm{K} / \mathrm{Ca}$ & - \\
$(\mathrm{Ca}+\mathrm{Na}+\mathrm{Mg}+\mathrm{K}) / \mathrm{P}$ \\
\hline Static & 1.53 & 0.05 & 0.042 & - & 1.67 \\
Agitated & 1.57 & 0.04 & 0.039 & - & 1.69 \\
Flow perfusion & 1.51 & 0.04 & 0.042 & 1.64 \\
\hline
\end{tabular}

Fig. 7 presents the lateral sides of the scaffolds after coating for 14 days in the different studied conditions, and the bottom side of the scaffold after coating by flow perfusion. The average thickness of the produced apatite layers was measured by SEM observation of the obtained cross-sections in the centre of the scaffolds. Fig. 7 also presents a SEM micrograph illustrating the procedure used to perform the measurements, starting from the basis of the apatite nuclei to the interface and the calculated average thickness of the apatite layers measured per condition $(n=6)$.

For all the studied conditions the integrity of the apatite layer nucleated in static SBF (Fig. 3) was maintained during the growth stage, even under dynamic conditions. The apatite layers have grown and clearly cover the fibers without compromising the overall morphology and porosity of
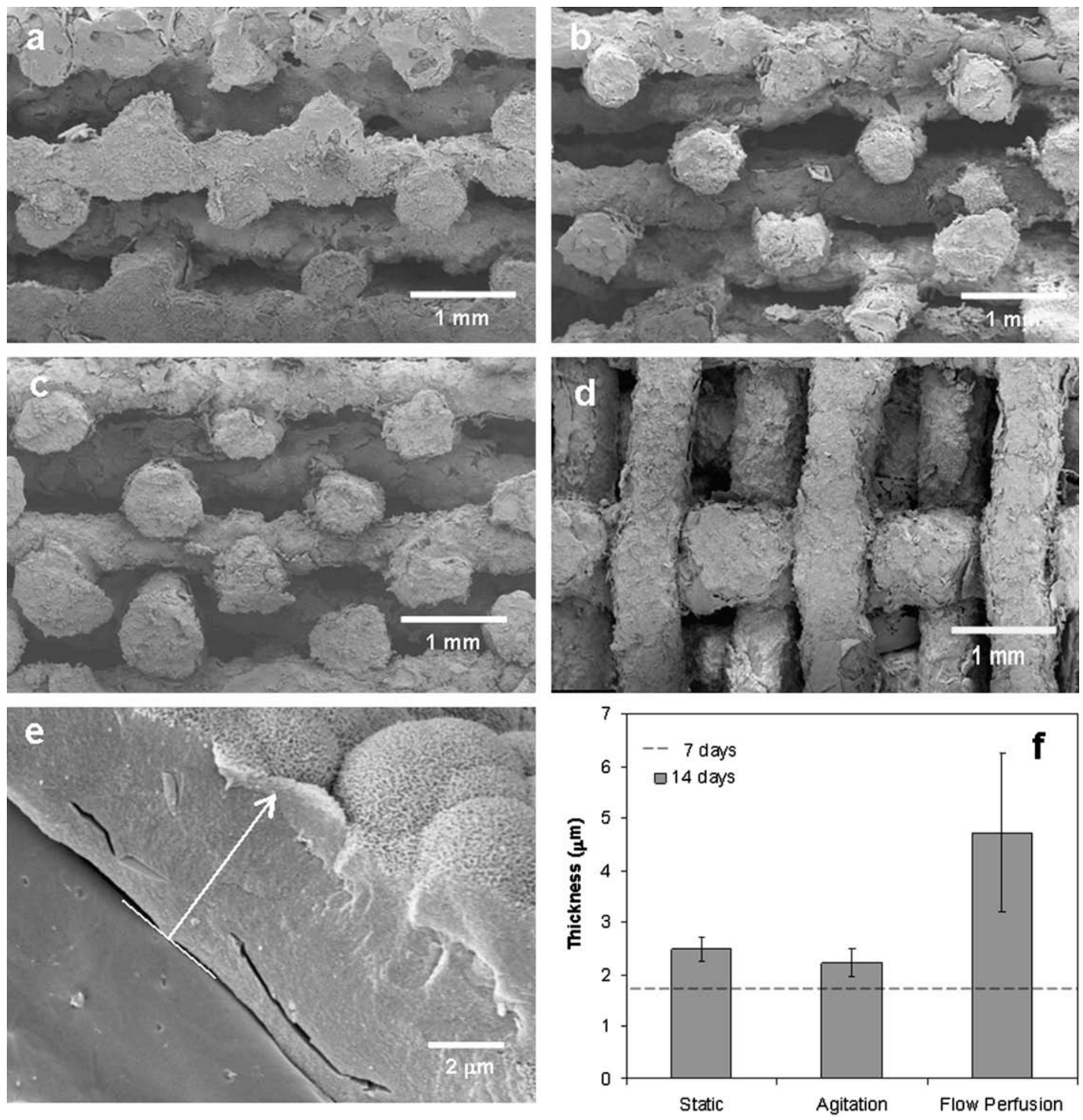

Fig. 7. SEM micrographs of the lateral sides of the scaffolds after immersion in SBF for 14 under (a) static, (b) agitated and (c) flow perfusion conditions. (d) Bottom side of the sample in (c). (e) Cross-section in the middle region. (f) Average thickness of the apatite coatings formed during the biomimetic process under static and dynamic conditions $(n=6)$. 
the scaffold. This indicates that the mineralization process was clearly controlled by the surface, which acted as a template for the nucleation and growth of the apatite layer. Nevertheless, under the static condition (Fig. 7a), apatite tended to accumulate in some of the intersections of the fibers, particularly those in its outer region. A possible explanation for this effect could be a local increase in the concentration of $\mathrm{Ca}^{2+}$ and $\mathrm{PO}_{4}^{3-}$ ions in $\mathrm{SBF}$ which will induce a higher formation of apatite in those restricted areas. In case of the agitated (Fig. 7b) and flow perfusion (Fig. 7c and d) conditions, apatite coating has shown to better follow the contours of the fibers. When considering the cross-sections of the centre of the scaffolds (Fig. 7e) it was possible to confirm the presence of an apatite layer in all the studied conditions, which did not detach even after being subjected to high-vacuum environments during sputtering and SEM analysis, and also to shear stresses during cross-section preparation.

After 7 days of immersion in SBF the measured apatite thickness was $1.77 \pm 0.31 \mu \mathrm{m}$ (Fig. 7f). Subsequent immersion in SBF allowed the apatite layer to grow, particularly in the case of the flow perfusion condition where the rate of apatite formation was significantly higher. After 14 days, the calculated average thickness for the coatings grown in static conditions was $2.49 \pm 0.23 \mu \mathrm{m}$; similar values $(2.22 \pm 0.26 \mu \mathrm{m})$ were obtained when agitation of the SBF was present, while for the flow perfusion condition the coating thickness was greatly enhanced to values of $4.70 \pm 1.51 \mu \mathrm{m}$. In this case, the calculated thickness presented a higher standard deviation, due to a thickness gradient observed from the bottom to the top of the apatite scaffolds. In fact the fibers from the bottom surface which were facing the flow presented a higher thickness, corresponding to the values in the upper limit of the error bar. This result can be explained from a hydrodynamic perspective. During apatite growth $\mathrm{Ca}^{2+}$ and $\mathrm{PO}_{4}^{3-}$ ions will be depleted from the surrounding SBF, leading to local concentration gradients. The rate of apatite formation will be dependent on the rate of diffusion of these ions at the boundary layer present at the interface between the growing apatite crystals and the fluid [55]. In a flowing system these concentration gradients will be eliminated. However, the side facing the flow will have more access to ions in $\mathrm{SBF}$, since the SBF flow rate is higher at the entrance of the chamber than in its centre.

Fig. 8 presents high magnifications of the typical morphologies of the apatite coatings grown on the surfaces of the SPCL scaffolds under the different static and dynamic conditions. Fig. 8a-c correspond to the same side of the scaffold, the side facing down during the biomimetic process. Fig. 8d corresponds to the same condition as Fig. 8c (flow perfusion) and to the upper side of the scaffold.

The produced apatite layers present the typical needlelike morphology. This nanoapatite structure was well defined in case of the static condition (Fig. 8a). When agitation was present (Fig. 8b) the size of the needles tended to decrease. In the case of flow perfusion this decrease was more accentuated, leading to a densification of the apatite structure at the side of the scaffold facing the flow (Fig. 8c). However, on the opposite side a different morphology was observed (Fig. 8d). In this case the needle-like structure was again more defined and smaller globular structures were formed in the coating. In this sense, the surface morphology of the apatite layers was influenced by the different conditions studied.

\section{Discussion}

When the concept of biomimetic coatings emerged in the early 1990s there was an immediate concern about improving coating efficiency by (among others) reducing the time required for apatite formation [56]. This was immediately reflected in a study by Hata and Kokubo [27] in which the apatite formation rate was greatly enhanced by increasing the concentration of the SBF, its temperature, or even by including agitation in the system. The first option has been explored quite extensively in recent years [57,58]. For example, Barrere et al. [57] accelerated the classical biomimetic process from 7 to 14 days to 1 day by immersing substrates in supersaturated $\operatorname{SBF}(5 \times \mathrm{SBF})$, and illustrated systematically the interdependence of ionic strength, $\mathrm{pH}$, carbonate concentration, and their collective influence, on the formation of the resultant apatite. However, extremely highly concentrated SBF solutions can frequently lead to spontaneous precipitation caused by homogeneous nucleation phenomena, making the coating process unstable and difficult to control, which can lead apatite layers with lower adhesion to the substrates. Moreover, the obtained $\mathrm{Ca}-\mathrm{Ps}$ may be different from those formed at more physiological concentrations. Other approaches include the use of highly reactive nucleating agents at the surface [22], performing several surface modifications [40,59], varying the SBF composition [60] or even increasing the temperature of the process $[29,55]$.

As demonstrated in the present study, dynamic conditions can also accelerate the process for apatite formation in a pre-established apatite layer while maintaining the composition, crystallinity and chemical structure of the apatites. Nevertheless, only a few authors [33-37] have studied the induction and growth of an apatite layer on the surface of bioactive materials on dynamic SBF. In fact, to the authors' knowledge, this kind of approach has been only proposed for accessing the SBF in vitro mineralization of materials with intrinsic bioactivity, such as silicabased ceramics [33,35-37] or their composites [34]. Besides better mimicking bone mineralization, the rationale for these studies was also intended to avoid the local build up of released silicic acid and ions from the silica-containing materials to the SBF solutions, which will influence the formation of the apatite layers. In a study to test the bioactivity of $\mathrm{CaSiO}_{3}$ ceramics Siriphannon et al. [36] obtained thinner apatite layers by using dynamic conditions. Salinas et al. [37] have also studied the apatite-forming ability of similar systems and reported a delay in apatite formation. 

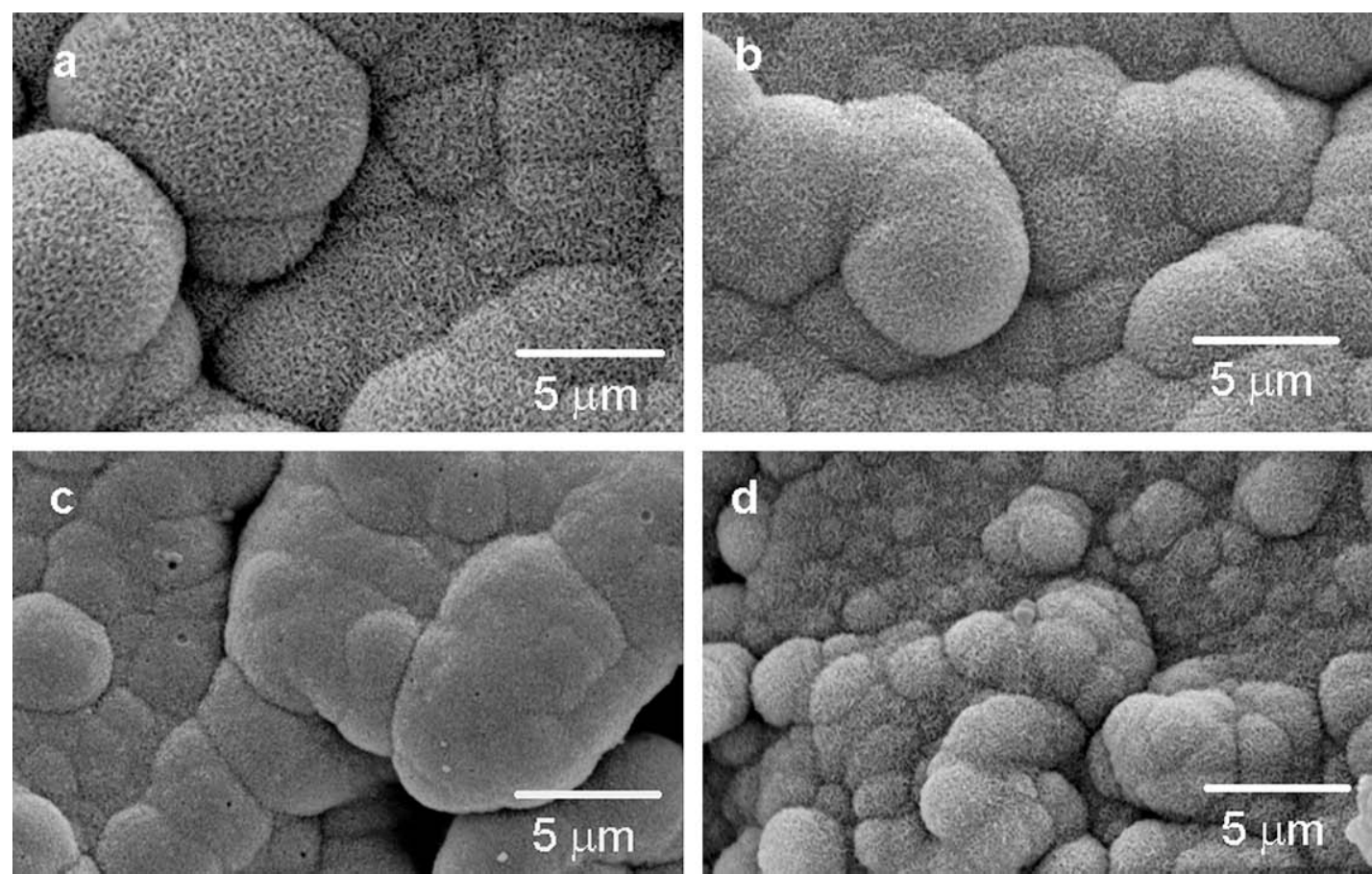

Fig. 8. Morphology of apatite coatings grown on the bottom side of the SPCL scaffolds after immersion in SBF for 14 days under (a) static, (b) agitation and (c) flow perfusion conditions. (d) Apatite coating grown on the upper side of sample under condition (c).

Although no straight comparison can be established due to the different conditions used (e.g. solid/liquid ratio, flow rate), the high dissolution ability of the substrate is certainly playing a role during apatite formation. These results support the authors' chosen strategy of promoting the nucleation of a stable apatite layer in static conditions prior to studies under dynamic conditions.

Flow perfusion was the most effective apatite coating procedure, leading to a higher rate of apatite formation. In this case the time necessary for the coating process can be greatly reduced. Other advantages of this system when compared with simple agitation and static conditions include avoiding the accumulation of precipitates, allowing for a better control of coating process by controlling the flow rate. On the other hand, the scaffolds can better preserve their integrity since they are static in the chamber, which does not occur under agitation. A disadvantage of flow perfusion was the thickness gradient found in the apatite layer from the bottom to the top of the scaffold. Nevertheless, this effect can be clearly overcome by periodically alternating the flow direction inside the chamber, allowing for a more homogeneous distribution of the layer thickness.

\section{Conclusions}

Bone-like apatite layers have been effectively produced, on the surface and in the interior of newly developed SPCL scaffolds produced by a RP technology. Sodium silicate treatment followed by immersion in SBF has resulted, after only $6 \mathrm{~h}$, in the nucleation of an amorphous $\mathrm{Ca}-\mathrm{P}$ layer that can grow into a bone-like, poorly crystalline, carbonated apatite layer covering the entire surface of the fibers while maintaining their initial porous structure and interconnectivity. This indicates that the mineralization process was clearly controlled by the surface, which acted as a template for the nucleation and growth of the apatite layer. During the growing stage apatite layers were formed under static, agitated and flow perfusion conditions. This last condition was able to accelerate the process for apatite formation while maintaining its composition, crystallinity and chemical structure. Moreover, besides mimicking better the biological environment, this dynamic process allowed for the coating of more stable and well-defined apatite layers on the surface of complex 3D architectures.

\section{Acknowledgements}

The authors acknowledge the Portuguese Foundation for Science and Technology (PhD grant to A.L.O., SFRH/BD/ 10956/2002 and post-doctoral Grant to R.A.S., SFRH/ BPD/17151/2004, under the POCTI Program). This work was partially supported by FCT through POCTI and/or FEDER programmes and also partially supported by the EU Project HIPPOCRATES (NMP3-CT-2003-505758) and EXPERTISSUES (NMP-CT-2004-500283).

\section{References}

[1] Hutmacher DW, Schantz T, Zein I, Ng KW, Teoh SH, Tan KC. Mechanical properties and cell cultural response of polycaprolactone scaffolds designed and fabricated via fused deposition modeling. J Biomed Mater Res 2001;55(2):203-16. 
[2] He S, Timmer MD, Yaszemski MJ, Yasko AW, Engel PS, Mikos AG. Synthesis of biodegradable poly(propylene fumarate) networks with poly(propylene fumarate)-diacrylate macromers as crosslinking agents and characterization of their degradation products. Polymer 2001;42(3):1251-60.

[3] Mooney DT, Mazzoni CL, Breuer C, McNamara K, Hern D, Vacanti JP, et al. Stabilized polyglycolic acid fibre based tubes for tissue engineering. Biomaterials 1996;17(2):115-24.

[4] Sachlos E, Reis N, Ainsley C, Derby B, Czernuszka JT. Novel collagen scaffolds with predefined internal morphology made by solid freeform fabrication. Biomaterials 2003;24(8):1487-97.

[5] Solchaga LA, Dennis JE, Goldberg VM, Caplan AI. Hyaluronic acidbased polymers as cell carriers for tissue-engineered repair of bone and cartilage. J Orthopaed Res 1999;17(2):205-13.

[6] Tuzlakoglu K, Alves CM, Mano JF, Reis RL. Production and characterization of chitosan fibers and 3D fiber mesh scaffolds for tissue engineering applications. Macromol Biosci 2004;4(8): $811-9$.

[7] Marques AP, Cruz HR, Coutinho OP, Reis RL. Effect of starchbased biomaterials on the in vitro proliferation and viability of osteoblast-like cells. J Mater Sci Mater Med 2005;16(9):833-42.

[8] Gomes ME, Reis RL, Cunha AM, Blitterswijk CA, de Bruijn JD. Cytocompatibility and response of osteoblastic-like cells to starchbased polymers: effect of several additives and processing conditions. Biomaterials 2001;22(13):1911-7.

[9] Malafaya PB, Gomes ME, Salgado AJ, Reis RL. Polymer based scaffolds and carriers for bioactive agents from different natural origin materials. Adv Exp Med Biol 2003;534:201-33.

[10] Gomes ME, Ribeiro AS, Malafaya PB, Reis RL, Cunha AM. A new approach based on injection moulding to produce biodegradable starch-based polymeric scaffolds: morphology, mechanical and degradation behaviour. Biomaterials 2001;22(9):883-9.

[11] Gomes ME, Sikavitsas VI, Behravesh E, Reis RL, Mikos AG. Effect of flow perfusion on the osteogenic differentiation of bone marrow stromal cells cultured on starch-based three-dimensional scaffolds. J Biomed Mater Res A 2003;67(1):87-95.

[12] Tuzlakoglu K, Bolgen N, Salgado AJ, Gomes ME, Piskin E, Reis RL. Nano- and micro-fiber combined scaffolds: a new architecture for bone tissue engineering. J Mater Sci Mater Med 2005;16(12): 1099-104.

[13] Silva GA, Coutinho OP, Ducheyne P, Shapiro IM, Reis RL. Starchbased microparticles as vehicles for the delivery of active plateletderived growth factor. Tissue Eng 2007;13(6):1259-68.

[14] Yang SF, Leong KF, Du ZH, Chua CK. The design of scaffolds for use in tissue engineering. Part 1. Traditional factors. Tissue Eng 2001;7(6):679-89.

[15] Salgado AJ, Coutinho OP, Reis RL, Davies JE. In vivo response to starch-based scaffolds designed for bone tissue engineering applications. J Biomed Mater Res 2007;80(4):983-9.

[16] Chim H, Hutmacher DW, Chou AM, Oliveira AL, Reis RL, Lim TC, et al. A comparative analysis of scaffold material modifications for load-bearing applications in bone tissue engineering. Int $\mathbf{J}$ Oral Maxillofacial Sur 2006;35(10):928-34.

[17] Hutmacher DW, Sittinger M, Risbud MV. Scaffold-based tissue engineering: rationale for computer-aided design and solid free-form fabrication systems. Trends Biotechnol 2004;22(7):354-62.

[18] Gomes ME, SAJ, Reis R. L. In: Reis RL, Cohn D, editors. Bone tissue engineering using starch based scaffolds obtained by different methodologies. NATO/ASI Series. Dordrecht: Kluwer; 2002. p. 221-49.

[19] Rey C. Calcium phosphate biomaterials and bone mineral. Differences in composition, structures and properties. Biomaterials 1990;11:13.

[20] Oliveira AL, Mano JF, Reis RL. Nature-inspired calcium phosphate coatings: present status and novel advances in the science of mimicry. Curr Opin Solid St M 2003;7(4-5):309-18.

[21] Abe Y, Kokubo T, Yamamuro T. Apatite coating on ceramics, metals and polymers utilizing a biological process. J Mater Sci Mater M 1990;1(4):233-8.
[22] Oliveira AL, Malafaya PB, Reis RL. Sodium silicate gel as a precursor for the in vitro nucleation and growth of a bone-like apatite coating in compact and porous polymeric structures. Biomaterials 2003;24(15):2575-84.

[23] Oliveira AL, Reis RL. Pre-mineralisation of starch/polycrapolactone bone tissue engineering scaffolds by a calcium-silicate-based process. J Mater Sci Mater Med 2004;15(4):533-40.

[24] Leonor IB, Kim HM, Balas F, Kawashita M, Reis RL, Kokubo T, et al. Functionalization of different polymers with sulfonic groups as a way to coat them with a biomimetic apatite layer. J Mater Sci Mater Med 2007;18(10):1923-30.

[25] Oliveira AL, Mano JF, Reis RL. Nature-inspired calcium phosphate coatings: present status and novel advances in the science of mimicry. Curr Opin Solid State Mater Sci 2003;7(4-5):309-18.

[26] Tuzlakoglu K, Reis RL. Formation of bone-like apatite layer on chitosan fiber mesh scaffolds by a biomimetic spraying process. J Mater Sci Mater Med 2007;18(7):1279-86.

[27] Hata K, Kokubo T, Nakamura T, Yamamuro T. Growth of a bonelike apatite layer on a substrate by a biomimetic process. J Am Ceram Soc 1995;78(4):1049-53.

[28] Barrere F, van Blitterswijk CA, de Groot K, Layrolle P. Nucleation of biomimetic Ca-P coatings on Ti6Al4V from a SBF $\times 5$ solution: influence of magnesium. Biomaterials 2002;23(10):2211-20.

[29] Li PJ. Biomimetic nano-apatite coating capable of promoting bone ingrowth. J Biomed Mater Res A 2003;66A(1):79-85.

[30] Chikara Ohtsuki MKTM. Coating bone-like apatite onto organic substrates using solutions mimicking body fluid. J Tissue Eng Regenerative Med 2007;1(1):33-8.

[31] Tate MLK. "Whither flows the fluid in bone?" An osteocyte's perspective. J Biomech 2003;36(10):1409-24.

[32] Meinel L, Karageorgiou V, Fajardo R, Snyder B, Shinde-Patil V, Zichner L, et al. Bone tissue engineering using human mesenchymal stem cells: effects of scaffold material and medium flow. Ann Biomed Eng 2004;32(1):112-22.

[33] Ramila A, Vallet-Regi M. Static and dynamic in vitro study of a solgel glass bioactivity. Biomaterials 2001;22(16):2301-6.

[34] Eglin D, Ali SAM, Perry CC. Comparative study of the in vitro apatite-forming ability of poly(epsilon-caprolactone)-silica sol-gels using three osteoconductivity tests (static, dynamic, and alternate soaking process). J Biomed Mater Res A 2004;69A(4):718-27.

[35] Vallet-Regi M, Perez-Pariente J, Izquierdo-Barba I, Salinas AJ. Compositional variations in time calcium phosphate layer growth on gel glasses soaked in a simulated body fluid. Chem Mater 2000;12(12):3770-5.

[36] Siriphannon P, Kameshima Y, Yasumori A, Okada K, Hayashi S. Comparative study of the formation of hydroxyapatite in simulated body fluid under static and flowing systems. J Biomed Mater Res 2002;60(1):175-85.

[37] Salinas AJ, Vallet-Regi M, Izquierdo-Barba I. Biomimetic apatite deposition on calcium silicate gel glasses. J Sol-Gel Sci Technol 2001;21(1-2):13-25.

[38] Reis RL, Cunha AM, Allan PS, Bevis MJ. Mechanical behaviour of injection-moulded starch based polymers. Polym Adv Technol 1996;7: 784-90.

[39] Reis RL, Cunha AM. Characterization of two biodegradable polymers of potential application within the biomaterials field. J Mater Sci Mater Med 1995;6:786-92.

[40] Oliveira AL, Elvira C, Vásquez B, San Roman J, Reis RL. Surface modifications tailors the characteristics of biomimetic coatings nucleated on starch based polymers. J Mater Sci Mater Med 1999; 10:827.

[41] Elvira C, Mano JF, San Roman J, Reis RL. Starch-based biodegradable hydrogels with potential biomedical applications as drug delivery systems. Biomaterials 2002;23(9):1955-66.

[42] Gomes ME, Holtorf HL, Reis RL, Mikos AG. Influence of the porosity of starch-based fiber mesh scaffolds on the proliferation and osteogenic differentiation of bone marrow stromal cells 
cultured in a flow perfusion bioreactor. Tissue Eng 2006;12(4):801-9.

[43] Gomes ME, Sikavitsas VI, Behravesh E, Reis RL, Mikos A G. Effect of flow perfusion on the osteogenic differentiation of bone marrow stromal cells cultured on starch based three-dimensional scaffolds. J Biomed Mater Res 2003;67A:87-95.

[44] Santos MI, Fuchs S, Gomes ME, Unger RE, Reis RL, Kirkpatrick CJ. Response of micro- and macro-vascular endothelial cells to starch-based fiber meshes for bone tissue engineering. Biomaterials 2007;28(2):240-8.

[45] Kokubo T, Kushitani H, Sakka S, Kitsugi T, Yamamuro T. Solutions able to reproduce in vivo surface-structure changes in bioactive glassceramic A-W. J Biomed Mater Res 1990;24(6):721-34.

[46] Oliveira AL, Costa SA, Sousa RA, Reis RL. Studies on the formation of biomimetic apatite layers on 3D-printed biodegradable polymeric scaffolds: effect of different dynamic coating routes. Society for Biomaterials 2006 Annual Meeting, Pittsburgh, 2006.

[47] Pawlak A, Mucha A. Thermogravimetric and FTIR studies of chitosan blends. Thermochim Acta 2003;396(1-2):153-66.

[48] Walsh D, Furuzono T, Tanaka J. Preparation of porous composite implant materials by in situ polymerization of porous apatite containing epsilon-caprolactone or methyl methacrylate. Biomaterials 2001;22(11):1205-12.

[49] Takadama H, Kim HM, Kokubo T, Nakamura T. Mechanism of biomineralization of apatite on a sodium silicate glass: TEM-EDX study in vitro. Chem Mater 2001;13(3):1108-13.

[50] Takadama H, Kim HM, Kokubo T, Nakamura T. X-ray photoelectron spectroscopy study on the process of apatite formation on a sodium silicate glass in simulated body fluid. J Am Ceram Soc 2002;85(8):1933-6.
[51] Vallet-Regi M, Romero AM, Ragel CV, LeGeros RZ. XRD, SEMEDS, and FTIR studies of in vitro growth of an apatite-like layer on sol-gel glasses. J Biomed Mater Res 1999;44(4):416-21.

[52] Rehman I, Bonfield W. Characterization of hydroxyapatite and carbonated apatite by photo acoustic FTIR spectroscopy. J Mater Sci-Mater M 1997;8(1):1-4.

[53] Boskey AL, Posner AS. Magnesium stabilization of amorphous calcium-phosphate—kinetic study. Mater Res Bull 1974;9(7):907-16.

[54] Miyaji F, Kim HM, Handa S, Kokubo T, Nakamura T. Bonelike apatite coating on organic polymers: novel nucleation process using sodium silicate solution. Biomaterials 1999;20(10):913-9.

[55] Tanahashi M, Kokubo T, Matsuda T. Quantitative assessment of apatite formation via a biomimetic method using quartz crystal microbalance. J Biomed Mater Res 1996;31(2):243-9.

[56] Kokubo T, Takadama H. How useful is SBF in predicting in vivo bone bioactivity? Biomaterials 2006;27(15):2907-15.

[57] Barrere F, van Blitterswijk CA, de Groot K, Layrolle P. Influence of ionic strength and carbonate on the Ca-P coating formation from SBFx5 solution. Biomaterials 2002;23(9):1921-30.

[58] Kim SS, Park MS, Gwak SJ, Choi CY, Kim BS. Accelerated bonelike apatite growth on porous polymer/ceramic composite scaffolds in vitro. Tissue Eng 2006;12(10):2997-3006.

[59] Oyane A, Kawashita M, Nakanishi K, Kokubo T, Minoda M, Miyamoto $\mathrm{T}$, et al. Bonelike apatite formation on ethylene-vinyl alcohol copolymer modified with silane coupling agent and calcium silicate solutions. Biomaterials 2003;24(10):1729-35.

[60] Li P, Ohtsuki C, Kokubo T, Nakanishi K, Soga N, Nakamura T, et al. Effects of ions in aqueous media on hydroxyapatite induction by silica gel and its relevance to bioactivity of bioactive glasses and glassceramics. J Appl Biomater 1993;4(3):221-9. 